\title{
PRELIMINARY STUDY OF THE INFLUENCE OF CONDUCTIVITY AND CALCIUM CONCENTRATIONS ON THE DENSITY AND SPECIES RICHNESS OF NATIVE AND INVASIVE GASTROPODS IN Grand Teton National PARK, WyOMing
}

\begin{abstract}
m

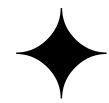

MICHELE LARSON $\uparrow$ GARY BEAUVAIS $\uparrow$ DEPARTMENT OF ZOOLOGY AND PHYSIOLOGY $\&$ PROgRAM IN ECOLOGY $\uparrow$ UNIVERSITY OF WYOMING $\uparrow$ LARAMIE
\end{abstract}

\section{$\uparrow \quad$ INTRODUCTION}

Freshwater gastropods are a diverse taxa that inhabit a wide variety of freshwater habitats (Lydeard et al. 2004, Strong et al. 2008). Freshwater gastropods often form narrow endemic ranges (Strong et al. 2008) with many species restricted to a single drainage or an isolated spring (Brown et al. 2008). In North America, over $60 \%$ of freshwater snails are listed as imperiled or presumed extinct (Lysne et al. 2008). The main factors for the reduction in snail biodiversity are habitat loss, water pollution, and the introduction of invasive species (Strong et al. 2008).

Invasive species can dramatically alter the native community by reducing biodiversity and changing ecological processes (Alonso and CastroDiez 2008). The effects of invasive species on aquatic ecosystems are often permanent and lead to reductions in biodiversity due to predation and competition with native species (Alonso and Castro-Diez 2008, Lysne et al. 2008, Strayer 1999). Invasive gastropods impact native ecosystems by altering carbon and nitrogen levels (Hall et al. 2003, Arango et al. 2009), consuming large amounts of primary producer biomass (Hall et al. 2003, Riley et al. 2008, Strayer 2010), and changing native macroinvertebrate community composition (Kerans et al. 2005, Riley et al. 2008, Cross et al. 2010, Brenneis et al. 2011).

Some invasive gastropods tolerate a wide range of abiotic environmental conditions including temperature and salinity (Alonso and Castro-Diez
2008). However, other environmental factors have received less attention, but may be important in determining the range of invasive snails and their impact on native gastropod populations. Conductivity and environmental calcium levels are important for growth and reproduction in gastropods (Kefford and Nugegoda 2005, Zalizniak et al. 2009) because decreased levels of calcium and other ions results in decreased shell strength, reduced locomotion, and increased metabolic demands (Hunter et al. 1967, Dalesman and Lukowiak 2010). A few studies have shown a direct relationship between conductivity and growth and reproduction in invasive snails. Herbst and colleagues (2008) reported that the invasive New Zealand mud snail, Potamopyrgus antipodarum, is tolerant of medium and high levels of specific conductivity and only showed decreased survival when conductivity was below $100 \mu \mathrm{S} / \mathrm{cm}$. In Australia, the invasive snail Physa acuta had lower growth and egg production in water with conductivity below $100 \mu \mathrm{S} / \mathrm{cm}$ (Kefford and Nugegoda 2005). However, few studies have examined the impact of conductivity on the distributions of native and invasive snail populations or the possible interactions between native and invasive snails for limited calcium ions.

Conductivity can also affect the species richness of gastropods. High conductivity is positively correlated with species richness of mollusks worldwide (Dillon 2000). In a study of 31 lakes in Northern Wisconsin, conductivity below $36 \mu \mathrm{S} / \mathrm{cm}$ resulted in lower snail species richness while lakes with higher than $50 \mu \mathrm{S} / \mathrm{cm}$ exhibited higher snail 
diversity (Hrabik et al. 2005). Yet, little research into the relationship between conductivity and gastropod species richness has been conducted in stream ecosystems.

Due to the impacts that invasive gastropods may have on native gastropod populations, it is important to identify the environmental factors that affect invasive gastropod populations. We conducted a preliminary field survey to test the hypothesis that conductivity is directly correlated with gastropod density and species richness.

\section{$\uparrow \quad$ METHODS}

We conducted a preliminary field survey along Polecat Creek in the John D. Rockefeller, Jr. Memorial Parkway. Sampling locations occurred above, at, and below the geothermal hot spring which corresponds to three conductivity levels (low, intermediate and high, respectively) in the stream. Geothermal springs increase the minerals available and conductivity of waters at and below their inputs (Herbst et al. 2008). To assess snail richness and abundance, we collected gastropods using a stovepipe sampler (20.4 cm diameter) from a single channel transect at each location. Gastropod samples were collected at five locations along each channel transect. We preserved samples in $70 \%$ ethanol immediately after collection and later counted and identified all snails to the lowest taxonomic level. We also counted the abundance of bivalves in each sample as bivalves may compete for calcium ions in areas where this mineral is limited. We also measured temperature, conductivity, total hardness, and salinity using an YSI probe and water quality test kits.

For our preliminary field study, we used a one-way ANOVA tests to determine whether abiotic factors (temperature, conductivity, etc.) and gastropod density (total snail density, the density of individual families, and snail richness) differed significantly among the three locations along Polecat Creek (Quinn and Keough 2002).

\section{PRELIMINARY RESULTS}

Of the abiotic factors measured between the three locations in Polecat Creek, temperature differed significantly among locations $(\mathrm{df}=2, \mathrm{~F}=35.014, \mathrm{p}<$ 0.001 ) while conductivity was nearly significant ( $\mathrm{df}=$ 2 , Kruskal-Wallis $=5.132, \mathrm{p}=0.077$; Table 1 ). The highest temperatures occurred at the site below the hot spring which was significantly different from the temperatures at the hot spring and above the hot spring. Conductivity was higher at the hot spring and below the hot spring than at the location above the hot spring (Table 1). Although water hardness did not differ significantly among locations $(\mathrm{df}=2, \mathrm{~F}=1.465$, $\mathrm{p}=0.303$ ), the overall trend was a reduction in total water hardness as locations moved downstream. Salinity was constant at all locations and therefore we did not assess statistically.

Table 1. Average abiotic factors for Polecat Creek, Wyoming at three sampling location. Standard deviation is shown in the parentheses.

\begin{tabular}{|c|c|c|c|c|}
\hline 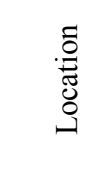 & 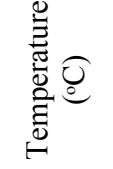 & : & 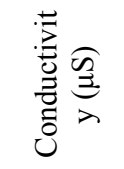 & 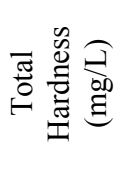 \\
\hline $\begin{array}{l}\text { Above } \\
\text { Spring }\end{array}$ & $\begin{array}{l}22.567 \\
(0.321)\end{array}$ & $\begin{array}{c}0.10 \\
(0.00)\end{array}$ & $\begin{array}{c}172.767 \\
(0.666)\end{array}$ & $\begin{array}{c}2.566 \\
(0.192)\end{array}$ \\
\hline $\begin{array}{l}\text { At Hot } \\
\text { Spring }\end{array}$ & $\begin{array}{l}23.233 \\
(0.153)\end{array}$ & $\begin{array}{c}0.10 \\
(0.00)\end{array}$ & $\begin{array}{l}192.167 \\
(30.277)\end{array}$ & $\begin{array}{c}2.334 \\
(0.667)\end{array}$ \\
\hline $\begin{array}{l}\text { Below } \\
\text { Spring }\end{array}$ & $\begin{array}{l}24.433 \\
(0.321)\end{array}$ & $\begin{array}{c}0.10 \\
(0.00)\end{array}$ & $\begin{array}{l}195.267 \\
(6.503)\end{array}$ & $\begin{array}{c}2.000 \\
(0.000)\end{array}$ \\
\hline
\end{tabular}

Table 2. Analysis of Variance results for snail abundance for Polecat Creek, Wyoming. The degrees of freedom (df), sum of squares (SS), mean squares (MS), f-ratio (F) and p-value $(\mathrm{P})$ are given for each statistical test. Bold numbers indicate significant $\mathrm{p}$-values.

\begin{tabular}{lccccc}
$\begin{array}{l}\text { Abiotic } \\
\text { Factor }\end{array}$ & df & SS & MS & F & P \\
\hline $\begin{array}{l}P . \\
\text { antipodarum }\end{array}$ & 2 & $14,418.53$ & $7,209.26$ & 1.351 & 0.296 \\
Native Snails & 2 & 115.73 & 57.87 & 2.52 & 0.122 \\
$\begin{array}{l}\text { Clams } \\
\begin{array}{l}\text { Snail Family } \\
\text { Richness }\end{array}\end{array}$ & 2 & 136.13 & 68.07 & 4.932 & $\mathbf{0 . 0 2 7}$ \\
& 2 & 1.73 & 0.87 & 1.3 & 0.308
\end{tabular}

Table 3. Mean abundance of mollusks as well as mean snail family richness for each location on Polecat Creek, Wyoming. Standard deviation is shown in the parentheses.

\begin{tabular}{lcccl} 
Location & \multicolumn{3}{c}{ Mean Mollusk Abundance } & $\begin{array}{l}\text { Mean } \\
\text { Snail }\end{array}$ \\
& $\begin{array}{l}\text { P. } \\
\text { antipodarum }\end{array}$ & $\begin{array}{c}\text { Native } \\
\text { snails }\end{array}$ & Clams & $\begin{array}{l}\text { Family } \\
\text { Richness }\end{array}$ \\
\hline Above & 36.2 & & 0.4 & \\
Spring & $(29.2)$ & $0.8(0.4)$ & $(0.5)$ & $2.0(0.7)$ \\
At Hot & 19.2 & & 7.6 & \\
Spring & $(17.7)$ & $7.2(8.1)$ & $(5.8)$ & $1.8(0.4)$ \\
Below & 91.8 & & 2.6 & \\
Spring & $(121.9)$ & $2.0(1.9)$ & $(2.7)$ & $2.6(1.1)$
\end{tabular}


There were no significant results among locations for snail abundance and family richness (Table 2). Although the abundance of $P$. antipodarum was not significantly different among locations $(\mathrm{p}=$ 0.296) the overall trend was for higher abundance of this invasive snail below the hot springs (Table 3). Alternatively, the native snails showed a slight, but non-significant $(\mathrm{p}=0.122)$ increase in abundance at the hot spring location. Family richness ranged from one to four families of snails with the highest richness at the below hot spring location (Table 2), however these results were not statistically significant $(\mathrm{p}=$ 0.308 ). Additionally, we collected data on native clam abundance at each location as bivalves may compete with snails for calcium resources. We found that clam abundance were significantly higher at the hot spring location than above the hot spring $(\mathrm{p}<0.03)$.

\section{$\uparrow$ DISCUSSION}

Because we only sampled one stream on one occasion and found high variance in conductivity and $P$. antipodarum density within locations, interpretation of our data is difficult. However, based on these preliminary data, we found that temperature and to a lesser extent conductivity follow the expected pattern of increased levels at and below the hot spring. The presence of a gradient in both temperature and conductivity is consistent with other research (Herbst et al. 2008) and validates the use of these locations (above, at, and below the hydrothermal spring) for our different conductivity levels in future studies. We will use more detailed water testing procedures in future studies to have more definitive results for different ions $(\mathrm{Ca}, \mathrm{Mg}, \mathrm{Cl}$, etc.).

Both native snail abundance and $P$. antipodarum abundance were not significantly different among locations, however, we found higher abundance of the invasive snail below the hydrothermal spring which is consistence with prior research (Herbst et al. 2008). Mean snail family richness was also found to be higher at the below hot springs location, however, these results were not significant, but may indicate that higher conductivity, temperature, or other factors may increase the richness of snails below hot springs. In our preliminary study, we found that both native snails and clams had higher abundances at the hot spring location while $P$. antipodarum abundance was lowest at this location (Table 3). These results may indicate that the hot spring provides a refuge for native mollusks by excluding $P$. antipodarum from the area. The underlying mechanism(s) for the low abundance of $P$. antipodarum cannot be determined based on our preliminary study; however, a wider range of water quality testing in future studies may provide insights into the underlying cause for the low abundance of $P$. antipodarum at hot spring locations.

\section{ACKNOWLEDGEMENTS}

We would like to thank the staff of Grand Teton National Park for allowing us access to work in Polecat Creek and to the staff at the University of Wyoming-National Park Service Research Center for accommodating us during our stay in the park. We are also grateful for funding provided by the Western Society of Malacologists.

\section{$\downarrow$ Literature Cited}

Alonso, A., and P. Castro-Diez. 2008. What explains the invading success of the aquatic mud snail Potamopyrgus antipodarum (Hydrobiidae, Mollusca)? Hydrobiologia 614(1): 107-116.

Arango, C. P., L. A. Riley, J. L. Tank, and R. O. Hall. 2009. Herbivory by an invasive snail increases nitrogen fixation in a nitrogenlimited stream. Canadian Journal of Fisheries and Aquatic Sciences 66(8): 1309-1317.

Brenneis, V. E., A. Sih, and C. E. de Rivera. 2011. Integration of an invasive consumer into an estuarine food web: Direct and indirect effects of the New Zealand mud snail. Oecologia 167(1): 169-179.

Brown, K. M., B. Lang, and K. E. Perez. 2008. The conservation ecology of North American pleurocerid and hydrobiid gastropods. Journal of the North American Benthological Society 27(2): 484-495.

Cross, W. F., E. J. Rosi-Marshall, K. E. Behn, T. A. Kennedy, R. O. Hall, A. E. Fuller, and C. V. Baxter. 2010. Invasion and production of New Zealand mud snails in the Colorado River, Glen Canyon. Biological Invasions 12(9): 3033-3043.

Dalesman, S., and K. Lukowiak. 2010. Effect of acute exposure to low environmental calcium on respiration and locomotion in Lymnaea stagnalis (L.). The Journal of Experimental Biology 213(9): 1471-1476.

Dillon, R. T. 2000. The Ecology of Freshwater Molluscs. Cambridge University Press, New York. 
Hall, R. O., J. L. Tank, and M. F. Dybdahl. 2003. Exotic snails dominate nitrogen and carbon cycling in a highly productive stream. Frontiers in Ecology and the Environment 1(8): 407-411.

Herbst, D. B., M. T. Bogan, and R. A. Lusardi. 2008. Low specific conductivity limits growth and survival of the New Zealand mud snail from the Upper Owens River, California. Western North American Naturalist 68(3): 324-333.

Hotchkiss, E. R., and R. O. Hall Jr. 2010. Linking calcification by exotic snails to stream inorganic carbon cycling. Oecologia 163(1): 235-244.

Hrabik, T. R., B. K. Greenfield, D. B. Lewis, A. I. Pollard, K. A. Wilson, and T. K. Kratz. 2005. Landscape-scale variation in taxonomic diversity in four groups of aquatic organisms: The influence of physical, chemical, and biological properties. Ecosystems 8(3): 301317.

Hunter, W. R., M. L. Apley, A. J. Burky, and R. T. Meadows. 1967. Interpopulation variations in calcium metabolism in the stream limpet, Ferrissia rivularis (Say). Science 155(3760): 338-340.

Kefford, B. J., and D. Nugegoda. 2005. No evidence for a critical salinity threshold for growth and reproduction in the freshwater snail Physa acuta. Environmental Pollution 134(3): 377383.

Kerans, B. L., M. F. Dybdahl, M. M. Gangloff, and J. E. Jannot. 2005. Potamopyrgus antipodarum: Distribution, density, and effects on native macroinvertebrate assemblages in the Greater Yellowstone Ecosystem. Journal of the North American Benthological Society 24(1): 123-138.

Lydeard, C., R. H. Cowie, W. F. Ponder, A. E. Bogan, P. Bouchet, S. A. Clark, and F. G. Thompson. 2004. The global decline of nonmarine mollusks. BioScience 54(4): 321-330.

Lysne, S. J., K. E. Perez. K. M. Brown, R. L. Minton, and J. D. Sides. 2008. A review of freshwater gastropod conservation: Challenges and opportunities. Journal of the North American Benthological Society 27(2): 463-470.

Miles, J., and M. Shevlin. 2001. Applying Regression and Correlation: A Guide for Students and Researchers. Sage Publications, London, UK.
Riley, L. A., M. F. Dybdahl, and R. O. Hall Jr. 2008. Invasive species impact: Asymmetric interactions between invasive and endemic freshwater snails. Journal of the North American Benthological Society 27(3): 509520.

Strayer, D. L. 1999. Effects of alien species on freshwater mollusks in North America. Journal of the North American Benthological Society $18: 74-98$.

Strayer, D. L. 2010. Alien species in fresh waters: Ecological effects, interactions with other stressors, and prospects for the future. Freshwater biology 55: 152-174.

Strong, E. E., O. Gargominy, W. F. Ponder, and P. Bouchet. 2008. Global diversity of gastropods (Gastropoda; Mollusca) in freshwater. Hydrobiologia 595:149-166.

Quinn, G. P., and M. J. Keough. 2002. Experimental Design and Data Analysis for Biologists. Cambridge University Press, Cambridge, UK.

Zalizniak, L., B. J. Kefford, and D. Nugegoda. 2009. Effects of different ionic compositions on survival and growth of Physa acuta. Aquatic Ecology 43(1): 145-156. 